\title{
Substitution of fossil fuel by industrial waste in clinker kilns
}

\author{
N. Kadel Jr., M. A. Sellitto, M. Borchardt \& G. M. Pereira \\ Production and Systems Engineering Graduate Program, \\ Unisinos, Brazil
}

\begin{abstract}
The purpose of this article is to report a case for the use of industrial solid waste in substitution of fossil fuel in clinker kilns in the cement industry. The partially replaced fossil fuels originated in the oil industry. The industry calls this practice co-processing. The research took place in a cement industrial complex located in South America. The research method was the action-research. This type of method uses existing theories to plan interventions in the field, while at the same time uses the results to generate theoretical advances. The studied company uses rice husk and scrap tires as alternative fuels in clinker kilns and decided to add a mixture of industrial solid waste, processed in a blending plant. The research defined the location of the blending plant; the definition of a direct-reverse integrated logistic network; and the economic and environmental impacts of co-processing. In prior research, a potential of 1,250 tons per month of waste generated in the region were detected, adequate for co-processing. The main results were: reduction of logistics costs of $27 \%$; reduction in fuel costs of $8 \%$; reduction of about 12,000 tons of fossil fuel per year; and reduction of about 36,000 tons of $\mathrm{CO}^{2}$ per year. An intangible gain in the company's strategy was a reduction in the dependence on oil international supply chains.
\end{abstract}

Keywords: co-processing, reverse logistics, waste management, clinker kilns, alternative fuels, cement industry, renewable energy, rice husks.

\section{Introduction}

Products are becoming obsolete more quickly, overloading the usual means of waste disposal in metropolitan regions. An alternative to reduce this overload is the return of materials by reverse logistics activities, like recycling, reuse, or 
remanufacturing [1]. Moreover, recent environmental laws made companies responsible for the entire lifecycle of their products, reinforcing the need to manage returns by reverse logistics activities [2]. Reverse logistics manages reverse flows that return discarded products of an industry, turning them into components, fuel or raw material for other industries [3].

The concept of reverse logistics has evolved over time. Terms like reverse flows and reverse channels appear in the literature since 1970, but related only with environmental concerns [4]. Pohlen and Farris [5] introduced the concept of flow direction by setting reverse logistics as the movement of goods in a distribution channel that operates in the opposite direction to the original. Reverse logistics can be defined as the process of planning, implementing and controlling the flow of returned materials, with the purpose of recovering a part of its remaining value, or at least promote an environmentally correct final disposal [6]. Synthesizing, reverse logistics is the process of moving back materials that have already been used or their residues in order to recover any portion of still remaining value or give proper disposal.

This article focuses on the Brazilian Cement Industry and co-processing. According to work promoted by ABCP - Brazilian Association of Portland Cement, most Brazilian affiliated companies are interested in co-processing industrial wastes as an alternative source of energy, preferably integrating the required logistics with the existing supply chain [7]. Such practice has a positive environmental impact: besides increasing the useful life of landfills, it can replace fossil fuels originally extracted from nature [8]. The aim of this paper is to implement a reverse logistics supply chain for the co-processing of industrial waste in a clinker plant. The research question is: how do we organize the reverse logistics supply chain for waste co-processing in a clinker plant? The research method used was the action research. The object is a cement industrial complex, located in Brazil. The specific objectives are: (i) identify potential supplies of waste viable for co-processing; (ii) define the location of the waste blending plant; and (iii) define the required reverse logistics.

\section{Reverse logistics}

For many companies it is necessary to manage a reverse channel, due to the fact that the life of their products doesn't end when consumed [9]. Reverse logistics activities include the reintroduction of products and materials returned after sale or consumption, as new raw materials or alternative fuel [10]. Some drivers to reverse logistics activities are: the recovery of the remaining value of used products, resulting in new and cheaper sources of raw materials or energy; legislation compliance; and the creation of a positive corporate image associated with socio-environmental initiatives [11]. The consequences of such practices include a longer useful life of landfills and the lowest use of incineration as a final destination [12].

Reverse logistics activities can be operated by a focal company or outsourced to logistics operators [13]. In both cases, understanding the inherent trade-offs in 
reverse network design is essential for the development of efficient reverse logistics networks [14]. In general, the factors that influence the network project can vary over time, generating uncertainty in decision [15].

Reverse logistics materialize through various reverse channels: (i) Recycling: comprises the extraction and separation of constituent materials of the returned goods, that turn into secondary raw materials for new products in the same or in another industry (e.g. papers, glass, metals); (ii) reuse: comprises returned goods that still have a useful life and can be resold or reused (e.g. household appliances, vehicles, equipment); (iii) remanufacturing: comprises rejected goods, for technical, commercial or aesthetic reasons, returned to be rebuilt or to provide parts for use in other products (e.g. household appliances, furniture, footwear, computers); and (iv) disposal: provides an adequate final disposal in landfills, incinerators, or industrial co-processing $[16,17]$.

\section{Cement manufacturing and co-processing in cement kilns}

Generally, the cement manufacturing includes: quarrying; primary crushing; blending of components (pre-homogenization); fine grinding (raw mill); burning at sintering temperatures (of up to $1,450^{\circ} \mathrm{C}$, with a flame temperature of about $2,000^{\circ} \mathrm{C}$ ) to produce the clinker in a rotary kiln; finish grinding in the cement mill (mixed with gypsum, fly ash, granulated blast furnace slag, pozzolanas, limestone, and other additives); packaging; and shipping in bags (25 or $50 \mathrm{~kg}$.), big bags (up to $500 \mathrm{~kg}$.) or in bulk trucks [18].

The clinker, produced in rotary kilns, is the most important component in cement. Kilns are used for the pyroprocessing stage of manufacture of cement. In cement kilns, calcium carbonate reacts with silica-bearing minerals to form a mixture of calcium silicates [19]. The capacity of the kiln usually defines the capacity of the entire cement plant [18]. As kilns are the main energy-consumer [19] and greenhouse-gas-emitter in a cement plant, improvements in kiln efficiency are important concerns in cement manufacturing management and technology. The cement industry produces about 5 to $7 \%$ of global antrophic $\mathrm{CO}_{2}$ emissions [20]: about 50\% of it come from the chemical process; $40 \%$ from burning fuel; and the rest from other sources [21]. In clinker kilns, expressive fraction of energy is lost in several forms, like hot flue gas and convection plus radiation from the cooler and the kiln shell [22].

A wide range of fuels can be used in cement kilns. Common fuels that are used are gas, oil, petcoke, or coal, and alternative materials such as waste oils, synthetic materials, auto shredded residues, scrap tires, sewage sludge, and slaughterhouse residues are also employed [23]. In rice-producing regions, such as southern Brazil, rice husk residues are also an important alternative fuel. The rice husk has lower calorific value above $3,200 \mathrm{kcal} / \mathrm{kg}$, as well as high silica content, which creates a positive contribution: the first contributes directly to the internal temperature; the second reduces the alkalinity level, allowing the use of petcoke with higher sulphur, abundantly available in international markets [24]. 
Reduction in energy consumption is a major motivation for technological and managerial advances in the cement industry. In order to reduce costs with fossil fuel, co-processing has been introduced in the industry [8]. Co-processing in clinker kilns is a process of high efficiency and high capacity of calorific value recovery: a kcal of residue fully replaces a kcal of fossil fuel and the residue is totally destroyed [25]. In co-processing, two or more wastes of different origin participate in the same process, as raw materials in manufacturing activities or alternative fuel in heat generation above $800^{\circ} \mathrm{C}$. Co-processing must occur without changing the gas emissions and the quality of the produced clinker [26]. Materials for co-processing can come from various sources: industrial waste; urban postconsumption waste; or biomass from urban services, agriculture or health care services [27]. According to WBCSD - SCI, The Netherlands, Switzerland, Austria and Germany substitute respectively about $83 \%, 48 \%, 46 \%$, and $42 \%$ of the main fuel in clinker kilns [28]. According to ABCP, Brazil substitutes about 22.5\% [7].

Technical advances and new regulations have stimulated co-processing. Industries with which residues are adequate for co-processing, such as paints, food, forestry, plastics, rubbers, agribusiness or furniture, have sponsored research efforts to make viable the use of their waste in industries that require large amounts of energy as the cement industry [29]. Co-processing is also stimulated by regulations involving extended producer responsibility, which makes manufacturers responsible for the entire lifecycle of their products. In many situations, companies of different industries must cooperate, combining efforts and integrating logistics networks with the purpose of matching available waste and existing heat generation processes [30]. The problem, generally, is more complex than the simple physical-chemical utilization of waste, since it requires the monitoring of emissions and may involve the installation of a reverse logistics network, in order to assure viability. The solution involves how to use efficiently the residue, as well as how to supply it continuously and economically [31].

Brazil generates around 2.7 million tons per year of industrial waste, but coprocesses in kilns only 800 thousand tons per year: 36 out of a total of 47 plants have environmental licensing for co-processing, corresponding to $80 \%$ of the national production of clinker [7]. In Brazil, some requirements of co-processing are established in official resolutions [32]: (i) the lower calorific value (LCV) must be greater than $2,700 \mathrm{kcal} / \mathrm{kg}$; in the case of blending, each residue must have LCV higher than $1,700 \mathrm{kcal} / \mathrm{kg}$; the impact of emissions shall not exceed that of incineration; and continuous monitoring of key components shall be provided by the involved companies.

\section{Research}

The research method was the action research. The main research technique was the participant observation. Action research is a family of research methodologies that aims to make an improvement by action and, simultaneously, produce a better understanding about the object of study [33]. In action research, knowledge is generated from the solution of a practical problem: there is a practical, 
real-world goal, as well as a goal of knowledge [34]. In this article, a problem was solved and a specific knowledge was produced: the organization of a network for the recycling of industrial waste and the role of reverse logistics activities in the cement industry.

Three companies participated of the study. The CP Company operates a cement manufacturing business in southern Brazil, in the state of Rio Grande do Sul (RS), formed by two units, a clinker producer and a cement mill shop. The main fuel is petcoke, mixed with rice husk and scrap tires. The EC Company provides technical support and consultancy on alternative fuels and co-processing. The PR Company provides environmentally correct solutions for a wide range of industrial waste. The main service is landfilling management, but PR also produces blends for co-processing with waste from various origins, according to the specs of the customers.

In the beginning of 2012, PR proposed to CP the construction of a plant for production of blend for co-processing in a clinker kiln, according to the specs issued by EC. The proposal was accepted and a research group was formed by the companies. The research group was formed by three scholars that gave theoretical and methodological support; two managers of PR, responsible for the blending plant; two managers of EC, responsible for product and market relations; and three managers of $\mathrm{CP}$, responsible for product performance, environmental licensing and logistics. The studied constructs were: the waste adequate for co-processing available in RS; the process of collecting waste; and the location of the plant and integration with the existing supply chain.

\subsection{Solid waste in RS}

PR gives three types of destinations to the received industrial waste: (i) direct co-processing, without treatment; (ii) waste center, where it is treated and blended, forming a final product, in accordance with specs; and (iii) final disposal in landfill sites, incineration, incorporation into soil, or recycling. PR operates only in RS. In 2010 , RS generated 189,203 tons of hazardous waste and 2,174,682 tons of non-hazardous registered waste of various types. Tables 1 and 2 present, respectively, the distribution of registered waste generated by the industry and the given destination at the time of the study [35].

In order to focus only on the waste adequate for co-processing, a survey was conducted with 84 companies licensed to supply waste for co-processing and prone to deliver it to PR. The amount of adequate waste reached 1,242.2 tons per month (circa $0.7 \%$ of the total amount of waste generated in RS) in December of 2012, which corresponds to about 15,000 tons per year, more than the required specification (12,000 tons per year). This is the amount that PR can count on to feed the blending plant. The generation is geographically distributed by micro-regions in RS, represented in a Cartesian plan, with a zero point at the center of the metropolitan region. Table 3 shows the localization of the centroids and the amount available per micro-region. 
Table 1: Waste generated in RS in 2009.

\begin{tabular}{|c|c|c|}
\hline Industry & Hazardous & Non-Hazardous \\
\hline Leather & 118,254 & 127,317 \\
\hline Mechanic & 20,800 & 121,290 \\
\hline Metallurgist & 20,624 & 296,472 \\
\hline Chemistry & 18,232 & 288,738 \\
\hline Paper & 2,291 & 253,776 \\
\hline Rubber & 1,504 & 10,278 \\
\hline Beverages & 1,347 & 165,562 \\
\hline Wood & 1,261 & 104,435 \\
\hline Textile & 1,214 & 11,789 \\
\hline Miscellaneous & 1,027 & 6,456 \\
\hline Electric-electronic & 962 & 3,308 \\
\hline Plastic & 940 & 13,895 \\
\hline Food & 490 & 665,451 \\
\hline Non-metallic minerals & 123 & 12,039 \\
\hline Tobacco & 82 & 47,697 \\
\hline Printing and publishing & 52 & \\
\hline Power generation & & 46,179 \\
\hline Total & 189,203 & $2,174,682$ \\
\hline
\end{tabular}

Table 2: Destination of waste generated in RS in 2009.

\begin{tabular}{|r|c|c|}
\hline Destination & Hazardous & Non-Hazardous \\
\hline Waste center & 71,546 & \\
\hline Industrial landfill & 42,863 & 158,096 \\
\hline Reuse, recycling, or remanufacture & 28,268 & $1,128,591$ \\
\hline Sent to other states & 18,592 & \\
\hline Incineration & 3,246 & 162,615 \\
\hline Other forms of destination & 24,688 & 366,819 \\
\hline Incorporation into soil & & 288,961 \\
\hline Animal feed industry & & 69,600 \\
\hline Total & 189,203 & $2,174,682$ \\
\hline
\end{tabular}


Table 3: Distribution of waste generated by geographic region.

\begin{tabular}{|c|c|c|}
\hline Micro-regions & Centroid localization $\mathrm{km}$ & Supply (t/month) \\
\hline Metropolitan Region & $(0 ; 0)$ & 974.6 \\
\hline Vale dos Sinos Region & $(35 ; 30)$ & 102.2 \\
\hline Serra Region & $(0 ; 100)$ & 97.2 \\
\hline West Region & $(-290 ; 60)$ & 50 \\
\hline South Region & $(-120 ;-100)$ & 16 \\
\hline Central South Region & $(-200 ;-110)$ & 2.5 \\
\hline Total & & $1,242.5$ \\
\hline
\end{tabular}

\subsection{The collection process}

Waste collection is the transfer of solid waste from the point of generation or disposal to the blending plant. Seven companies and five self-employed carriers were selected for the service. For companies, the criteria were: time of experience; image on the market and recommendation; number of owned vehicles; certifications; number of transit incidents and fines; and evaluation based on a technical inspection. For the self-employed carriers, the criteria were: working time with CP; number of transit incidents and fines; quality of vehicles; potential for further investment; and evaluation based on technical inspection.

Collecting procedure requires three activities: intermediate packaging at the point of waste generation; storage in buckets at the point of collection; and exchange of the full bucket by an empty one in the moment of shipping. Figure 1 shows the typical containers used in intermediate packaging.
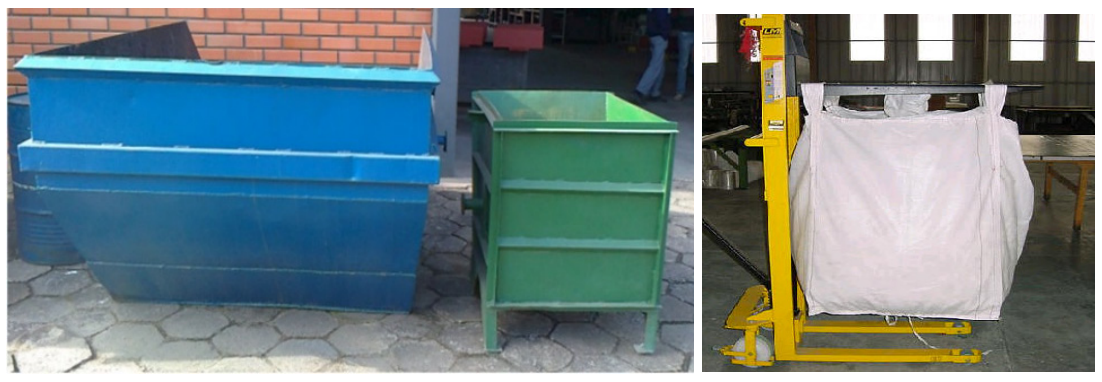

Figure 1: Typical containers used for waste at the generation point.

Waste generators were divided into small and large units. For small units, the collection occurs periodically, always at the same day and time, regardless of the amount collected, according to an optimized milk-run technique. The volume collected ranges between 3 and $10 \mathrm{~m}^{3}$. For big units, the collection occurs only with full load, and the route is point-to-point. The volume collected ranges between 15 and $30 \mathrm{~m}^{3}$. The buckets used in trucks are of two types: type I, between 3 and $7 \mathrm{~m}^{3}$; and type II, between 15 and $30 \mathrm{~m}^{3}$. The type of vehicle chosen is the Roll-on Roll-off truck, as shown in Figure 2. This figure also shows the two types of buckets used. 

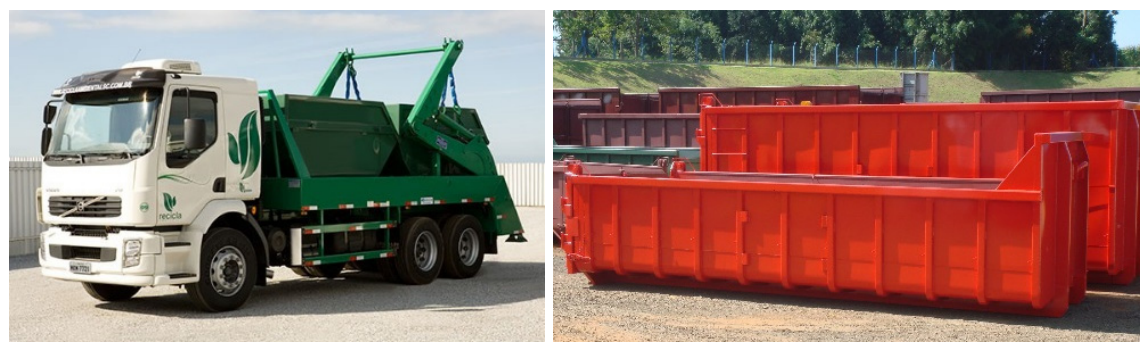

Figure 2: $\quad$ Truck and type I bucket (left); type II buckets (right).

\subsection{Location of the waste processing plant and integration with direct chain}

The waste processing plant requires six areas: (i) storage area for received solid waste; (ii) storage area for received pasty waste; (iii) primary crusher of solid residue, with magnetic separator for metallic parts; (iv) pasty material processor, which will be mixed with solid processed material; (v) warehouse of finished product; and (vi) bay for trucks and shipping area of finished product. The production batch shall be 30 tons, in order to synchronize with the daily demand of the rotary kiln.

Some assumptions were accepted to set the location of the plant: (i) the quantity (transit time $\mathrm{x}$ volume of waste) in trucks should be minimized to decrease the probability and severity of an eventual accident with environmental damage; (ii) shipping waste is more expensive than shipping finished product, due to the difference of density; and (iii) the transfer of finished product must be made in batches of 30 tons. Finished product logistics requires: transport between the processing plant and clinker plant; synchronism of receiving must be one batch per day for ten days, and two batches on the eleventh day, setting up about 12,000 tons per year; issuance of certificate of burning identifying the received lot, the generators and the type of residue; and the final cost of the operation must be less than the original cost based on the main fuel.

A location optimization problem was solved, involving probability and severity of accidents, economic feasibility, and possibility of logistic integration. Among some prior target locations, the best solution was provided by the city of Nova Santa Rita. The coordinates of the city in the Cartesian plan of RS are $(-6 ; 20)$. For the transportation of finished product, only two modalities were viable: point-topoint by trucks (440 km, seven hours); and multimodality combining train and trucks (regular railway line Nova Santa Rita-Candiota, transshipment to truck and excerpt of $20 \mathrm{~km}$ to the plant). Waterway transport was impracticable, given the required transfer batch $(4,500$ tons, more than the required quantity for four months of burning). The multimodality was chosen. The cost was about $27 \%$ cheaper than trucks only. The railroad Nova Santa Rita-Candiota is part of the direct logistic flow from the clinker plant to the cement mill shop of CP. So, the transportation of finished product integrates itself with the transportation of clinker, setting up a complete direct-reverse supply chain from and into the clinker plant. 


\subsection{Implications for the companies}

The main implication for CP was the partial replacement of fuel. After a year of implementation of the coprocessing, the substitution percentage is about $26.7 \%$ : 12,000 tons per year of waste out of an initial amount of 45,000 tons per year of petcoke. A cost reduction of about $8 \%$ was achieved, as well as a reduction in $\mathrm{CO}_{2}$ emissions of about 36,000 tons per year. Moreover, the dependence on the imported petcoke, susceptible to fluctuations on product price and international maritime freight, decreased. Finally, the volume transported by train increased, making it the most efficient modal in the supply chain.

The main implication for PR was the beginning of a new business, the co-processing. Before the beginning of the operation, the company only carried waste from one point to another. The main skill of PR for this new business is managing the supply of residue and combines it with the demand forecast of an industrial consumer. The study showed that it is faster and cheaper (about five times) to implement a co-processing coordinated operation in a clinker kiln, than to project, buy, and start-up an incineration facility to generate energy from the waste. After a year of operation, the company's revenue grew by approximately $16 \%$.

\section{Final remarks}

The purpose of this paper was to report a case for the use of industrial solid waste in the substitution of fossil fuel in clinker kiln in cement industry. An amount of about 12,000 tons of petcoke was substituted by a blending originated from processed waste. A logistic process had to be created and integrated with the existing supply chain.

Research produced economic and environmental results. The main economic results were: cost reduction in fuel acquisition; and the increase in the volume transported by rail, making this modal more efficient. The main environmental result was the reduction of $\mathrm{CO}_{2}$ emission, due to the reduction in fossil fuel; and the reduction of waste destined to landfills or other form of final disposal.

The analysis of the case shows that co-processing can be a sustainable energy alternative for the cement manufacturing. The research showed that co-processing can contribute to a reduction in the consumption of fossil fuels in industrial activity as well as provide an expressive cost reduction in the operation.

\section{References}

[1] Heese, H., Cattani, K., Ferrer, G., Gilland, W. \& Roth, A., Competitive advantage through take back of used products. European Journal of Operational Research, 164(1), pp. 143-157, 2005.

[2] Lai, K. \& Wong, C., Green logistics management and performance: Some empirical evidence from Chinese manufacturing exporters. Omega, 40(3), pp. 267-282, 2012. 
[3] Sheriff, K., Gunasekaran, A. \& Nachiappan, S., Reverse logistics network design: a review on strategic perspective. International Journal of Logistics Systems and Management, 12(2), pp. 171-194, 2012.

[4] Brito, M. \& Dekker, R., Reverse logistics: a framework. Econometric Institute. Report EI 2002-38, Erasmus University Rotterdam, The Netherlands, 2002.

[5] Pohlen, T. \& Farris, M., Reverse Logistics in Plastics Recycling. International Journal of Physical Distribution and Logistics Management, 22(7), pp. 34-47, 1992.

[6] Rogers, D., Melamedi, B. \& Lembkes, R., Modeling and Analysis of Reverse Logistics, Journal of Business Logistics, 33(2), pp. 107-117, 2012.

[7] ABCP, www.abcp.org.br (in Portuguese).

[8] Lamas, W.; Palau, J.; Camargo, J., Waste materials co-processing in cement industry: Ecological efficiency of waste reuse. Renewable and Sustainable Energy Reviews, 19(2), pp. 200-207, 2013.

[9] Atasu, A.; Toktay, L. \& Van Wassenhove, L., How collection cost structure drives a manufacturer's reverse channel choice. Production and Operations Management, 22(5), pp. 1089-1102, 2013.

[10] Bogataj, M. \& Grubbström, R., Transportation delays in reverse logistics. International Journal of Production Economics, 143(2), pp. 395-402, 2013.

[11] Chan, F., Chan, H. \& Jain, V., A framework of reverse logistics for the automobile industry. International Journal of Production Research, 50(5), pp. 1318-1331, 2012.

[12] Pokharel, S. \& Mutha, A., Perspectives in reverse logistics: A review. Resources, Conservation and Recycling, 53(2), pp. 175-182, 2009.

[13] Govindan, K., Palaniappan, M., Zhu, Q. \& Kannan, D., Analysis of third party reverse logistics provider using interpretive structural modeling. International Journal of Production Economics, 140(1), pp. 204-211, 2012.

[14] Barker, T. \& Zabinsky, Z., A multicriteria decision making model for reverse logistics using analytical hierarchy process. Omega, 39(5), pp. 558-573, 2011.

[15] Lee, D. \& Dong, M., Dynamic network design for reverse logistics operations under uncertainty. Transportation Research Part E: Logistics and Transportation Review, 45(1), pp. 61-71, 2009.

[16] Beullens, P., Reverse logistics in effective recovery of products from waste materials. Reviews in Environmental Science \& Bio/Technology, 3(4), pp. 283-306, 2004.

[17] Guide, V. \& Wassenhove, L. Managing product returns for remanufacturing. Production and Operations Management, 10(2), pp. 142-155, 2001.

[18] Sellitto, M., Artificial Intelligence: An Application in a Continuous Process Industry. Gestão e Produção, 9(3), pp. 363-376, 2002 (in Portuguese).

[19] Peray, K., The rotary cement kiln. Chemical Publishing Co.: New York, 1986. 
[20] Benhelal, E., Zahedi, G., Shamsaei, E. \& Bahadori, A. Global strategies and potentials to curb $\mathrm{CO}_{2}$ emissions in cement industry. Journal of Cleaner Production, 51(1), pp. 142-161, 2013.

[21] Scalenghe, R., Malucelli, F., Ungaro, F., Perazzone, L., Filippi, N. \& Edwards, A., Influence of 150 years of land use on anthropogenic and natural carbon stocks in Emilia-Romagna Region (Italy). Environmental Science \& Technology, 45(12), pp. 5112-5117, 2011.

[22] Engin, T. \& Ari, V., Energy auditing and recovery for dry type cement rotary kiln systems - A case study. Energy Conversion and Management, 46(4), pp. 551-562, 2005.

[23] Kääntee, U., Zevenhoven, R., Backman, R., \& Hupa, M., Cement manufacturing using alternative fuels and the advantages of process modelling. Fuel Processing Technology, 85(4), pp. 293-301, 2004.

[24] Sellitto, M., Kadel Jr, N., Borchardt, M., Pereira, G., Domingues, J. Rice husk and scrap tires co-processing and reverse logistics in cement manufacturing. Ambiente \& Sociedade, 16(1), 141-162, 2013.

[25] Hendriks, C., Worrell, E., De Jager, D., Blok, K. \& Riemer, P., Emission Reduction of Greenhouse Gases from the Cement Industry. Procs. of the 4th Int. Conf. on Greenhouse Gas Control Technologies, Interlaken, Switzerland, 1998.

[26] Cugini, A., Lett, R. \& Wender, I., Coal/oil co-processing mechanism studies. Energy Fuels, 3(2), pp. 120-126, 1989.

[27] Garcia, R., Moura, F., Bertolino, L. \& Brocchi, E., Industrial experience with waste co-processing and its effects on cement properties. Environmental Progress \& Sustainable Energy. Ahead of print. DOI: 10.1002/ep.11873, 2013.

[28] WBCSD - SCI, www.wbcsdcement.org.

[29] Huang, Q., Yang, Y. \& Wang, Q., Potential for serious environmental threats from uncontrolled co-processing of wastes in cement kilns. Environmental science \& technology, 46(24), pp. 13031-13032, 2012.

[30] Lifset, R., Atasu, A. \& Tojo, N., Extended Producer Responsibility. Journal of Industrial Ecology, 17(2), pp. 162-166, 2013.

[31] Su, Y., Gathitu, B. \& Chen, W., Efficient and cost effective reburning using common wastes as fuel and additives. Fuel, 89(9), pp. 2569-2582, 2010.

[32] CONAMA, www.mma.gov.br/conama (in Portuguese).

[33] French, S., Action research for practising managers. Journal of Management Development, 28(3), pp. 187-204, 2009.

[34] Altrichter, H., Kemmis, S., Mctaggart, R. \& Zuber-Skrrit, O., The Concept of action research. The Learning Organization, 9(3), pp. 125-131, 2002.

[35] FEPAM, www.fepam.rs.gov.br (in Portuguese). 